\title{
Composition and catch rate of folded cube fish pots in the sea of Tuban Regency
}

\author{
Adi Suhariyanto, Faizal Rachman", Eko Setyobudi, Riza Yuliratno Setiawan, Nahla \\ Alfiatunnisa, and Supardjo Supardi Djasmani \\ Department of Fisheries, Faculty of Agriculture, Universitas Gadjah Mada, Yogyakarta, Indonesia
}

\begin{abstract}
This study aimed to determine the composition and catch rate of folded cube fish pots in the seawater of the Tuban Regency. The research was conducted in December 2018 located in the Sokorejo, Tuban Regency, using 30 units of folded cube fish pots with a size of $50 \times 50 \times 50 \mathrm{~cm}^{2}$. The cube folded trap installation was done in 10 times of catch trip and installed in the morning. The catches were collected, identified, and measured for their individual length and weight. The crabs were measured for the length and width of their carapace. The catching result of folded cube fish pots was classified into five types which are fish group (48.97\%), crabs group (29.59 $\%$ ), swimmer crabs $(7.1 \%)$, Land hermit crab $(6.12 \%)$, and mud snails (8.16\%). The result showed that Two-spined Arm Swimming Crab (Charybdis anisodon) was the most dominant type of catch equal to $29.59 \%$ of the total catch, while other types of catch that were quite common are Pig Faced Leather Jacket (Paramonacanthus choirocephalus) (9.18\%), and Crescent Pearch (Terapon jarbua) (8.16\%). The average catch rate for folding cube was $32 \% /$ trip with a weighted average catch of $436.58 \mathrm{gr} /$ trip.
\end{abstract}

\section{Introduction}

Tuban Regency East Java Province is one of the regions which has potential marine resources, with coastline along $65 \mathrm{~km}$. The catch of fisheries production Tuban Regency in 2018 reach 11,078.00 tons. The fishing fleet consisted of the outboard motorboat as much as 3265 units and traditional boats up to 405 units [1]. Fisheries business particularly catch fisheries has a quick profit yielding characteristic (quick in giving result), despite having risks. Some several problems faced by fishermen in their activity of catching fish is dependent on the availability of marine resources and the natural condition. Fisheries catch activity is also affected by environmental change, which impacted the production of fish caught. The effort to get around this problem is by providing alternative fish catchings which can be used as a substitute or back up tools, so this activity will not be stopped and can be sustainably implemented.

\footnotetext{
*Corresponding author : faizal.rachman@mail.ugm.ac.id
} 
One of fishing tool mostly used by fishermen to catch fish is fish pot. Fish pot is a catching tool commonly known among fishermen in the Tuban area. Fish pot is a fish catching trap that needs bait to attract sea animals to get inside. It is classified as a passive catcher tool because it is settled down in a certain place and waits for prey to enter the trap. The form of Fish pot is akin to a cage or closed room, which makes fish not be able to escape. The basic principle of the fishing pot is by snaring fish' eyesight so they will be trapped inside, the other name of fishing pots, also known as a fishing basket [2]. Fish pot is a catching tool with various types and forms. Each type of fish pot commonly has its own specifications and specialties. Some fish pots are aimed to catch a certain species target, thus its design is adjusted according to the species target size. Fish pot is a type of fish traps that has various shapes such as cubic, log, dome, cylinder, half-round, and many other shapes. Fish pot is popularly used again to catch living reef fish. The catching process of fish pot is harmless, but the process of setting and picking up the trap often damaged coral reefs. This kind of fish pot is usually placed and taken by most fishermen by diving with a compressor. Fish pot is categorized as an eco-friendly catching tool if it is in accordance with the technical instructions of Marine and Fisheries Department in 2006, which is specified with lower bycatch, high quality catching result, harmless to the environment, not catching the protected species, not endangering the fishermen's safety, and not doing the catch in a prohibited area.

The operation of this fishing pot functioning fodder as an attractor that stimulates and attracts the fish's attention to come into a fishing pot. Fodder is one of impactful factor which affects catching success using fishing pot. Fodder plays a role as a decoy, which is able to stimulate certain fish both chemically and physically. This activity is done by the fisherman in Desa Sokorejo who commonly uses the fishing pot from the beam base. Despite that fact, folded cube fishing pots has never been implemented in the sea of Tuban. The fish pots hold potential as an eco-friendly fishing tool and hopefully can be implemented to improve the fish catching result in the sea of Tuban. Thus, scientific research is needed to assess how well the tool performs in the field by examining its catch composition and catch rate in the sea of Tuban. This research aimed to assess the catching composition and catching rate of folded cube fishing pot in the Tuban Regency. The result of this research should be able to provide information about fish catches and the catching rate of the tool. The results hopefully can be used as a contribution to develop and manage marine resources of the Tuban sea optimally and sustainably.

\section{Materials and Methods}

\subsection{Materials}

The tools used in this research were a motorboat, GPS (Global Positioning System), scales with 1 gr precision, a ruler with $0.1 \mathrm{~cm}$ precision, stationery, camera, and bucket. The catching tool used in this research was 30 units of folded cube fishing pots which are made from iron with $4 \mathrm{~mm}$ diameters. The frame was covered with polyethilene multifilament net with the mesh size is 1,5 inch with a total tool size is $50 \mathrm{~cm} \mathrm{x} 50 \mathrm{~cm} \times 50 \mathrm{~cm}$. Folded cube fishing pot has a mouth size of $25 \mathrm{~cm}$ with the mouth inward length of $15 \mathrm{~cm}$. The folded cube fishing pot was operated in a longline by a $448 \mathrm{~m}$ rope, which used to connect each fishing pot and float. This research was divided into four stages: preparation, setting, immersing, and hauling. The equipment was installed in the morning and soaked for 24 hours, then the catch results were calculated the following day and were collected for measurement based on their length, wide, and width. The construction of the folded cube fishing pot is shown in figure 1. 


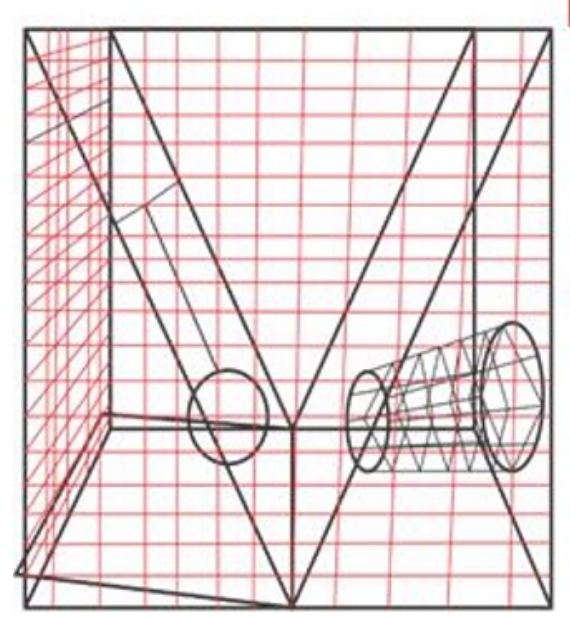

Fig. 1. The construction of folded cube fishing pot design

The materials used during the research were fodder and all catching fish result. The catching fish results were obtained from the research with fishing pot tools. The main fodder used was trash fish.

\subsection{Methods}

The methods used in this research was observation and experimental fishing method. The operation of the fish pot was done through lines that connected with a 448 meter rope and each point tied to the float with $14 \mathrm{~m}$ space from one point to another. The total number of fishing pots used was 30 units of folded cubes. The operation phase for each trip consisted of setting phase for 30 minutes, immersing phase of the tools for 24 hours, and hauling phase which needed 45 minutes. The fodder used were trash fish because it was easy to find and cheaper. The installation of the fish pots in the seawaters is shown in figure 2.

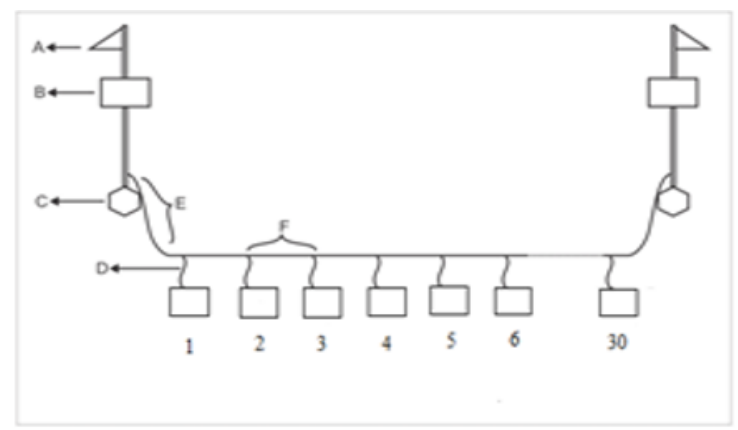

Fig. 2. Fishing pots installation plan. Explanation:
A. Marker Flag (Plastic and Lamp)
B. Float (Sterofoam)
C. Ballast (cement cast)
D. Strap $2 \mathrm{~m}$
E. Buoy Rope
F. Fish Pots Rope $14 \mathrm{~m}$ 
This research was conducted in Sokorejo Village, Jenu District, Tuban Regency, East Java, in December 2018. The catching activity was conducted in the sea of Tuban with 10 coordinate points of the capture locations. The catching tool's operation was done at 03.0012.00 WIB. The placement location of fishing pots during the research can be seen in figure 3.

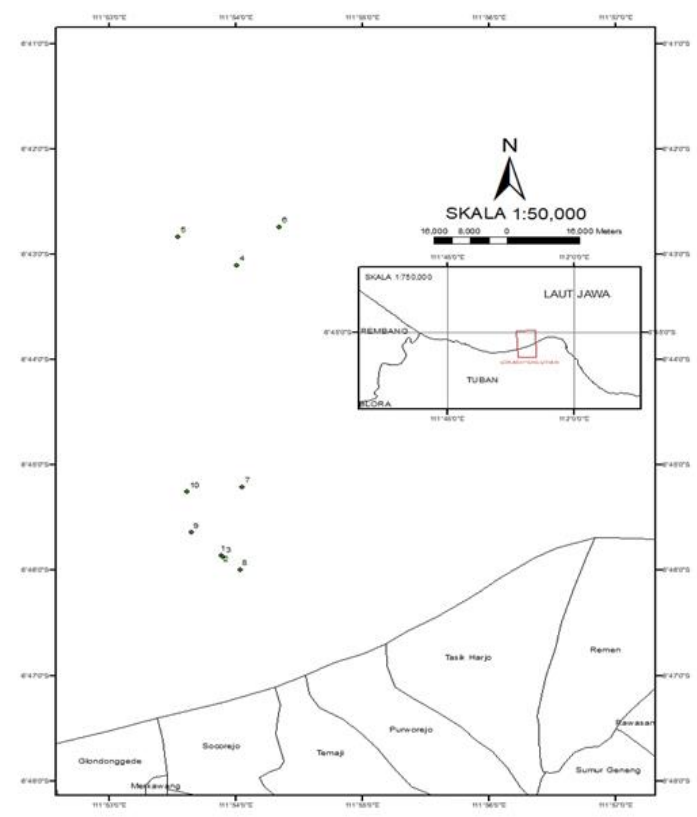

Fig. 3. Maps showing coordinate locations of folded cube fishing pot installation

\section{Result and Discussion}

\subsection{Result}

\subsubsection{Catch Result Composition}

The research result shows that folded cube fishing pot catch consisted of fish, swimmer crab, crabs, land hermit crab, and snail. In detail the result of folded cube fishing pot can be seen in table 1 below:

Table 1. Type of catch folded cube fishing pot in the sea of Tuban Regency

\begin{tabular}{llllll}
\hline No & Common Name & Species & $\overline{\%}$ & $\overline{\boldsymbol{x}}$ length & $\overline{\boldsymbol{x}}$ weight \\
\hline $\mathbf{1}$ & Pig Faced Leather Jacket & $\begin{array}{l}\text { Paramonacanthus } \\
\text { choirocephalus }\end{array}$ & $9.18 \%$ & 11.58 & 36.52 \\
$\mathbf{2}$ & Crescent Pearch & Terapon jarbua & $8.16 \%$ & 16.1 & 34 \\
$\mathbf{3}$ & Yellow-Lined Seaperch & Lutjanus rufolineatus & $5.10 \%$ & 5.78 & 7.88 \\
$\mathbf{4}$ & Vermiculated Spinefoot & Siganus vermiculatus & $5.10 \%$ & 24.5 & 192.33 \\
\hline
\end{tabular}




\begin{tabular}{|c|c|c|c|c|c|}
\hline 5 & Rockcod Fish & Epinephelus sp. & $5.10 \%$ & 23.6 & 180 \\
\hline 6 & Vachelli’s Glass Perchlet & Ambassis Vachelli & $5.10 \%$ & 9.3 & 27 \\
\hline 7 & Russell's Snapper & Lutjanus russeli & $3.06 \%$ & 16.6 & 83.33 \\
\hline 8 & Black-Spot Seaperch & Lutjanus fulviflamma & $3.06 \%$ & 16.16 & 60 \\
\hline 9 & Yellowfin Seabream & Acanthopagrus latus & $2.04 \%$ & 16.7 & 75 \\
\hline 10 & Threadfin Bream & Nemipterus sp. & $1.02 \%$ & 11.12 & 28.04 \\
\hline 11 & Fork-tailed Threadfin Bream & Nemipterus furcosus & $1.02 \%$ & 13.1 & 56 \\
\hline 12 & Malabar Blood Snapper & Lutjanus malabaricus & $1.02 \%$ & 6.32 & 7.56 \\
\hline 13 & Long-eyed Swimming Crab & Podopthalmus vigil & $3.06 \%$ & 11.23 & 111 \\
\hline 14 & Blue Swimmer Crab & Portunus Pelagicus & $3.06 \%$ & 3.2 & 5 \\
\hline 15 & Crucifix Crab & Charybdis feriatus & $1.02 \%$ & 13.83 & 206.66 \\
\hline 16 & $\begin{array}{l}\text { Twospined Arm Swimming } \\
\text { Crab }\end{array}$ & Charybdis anisodon & $29.59 \%$ & 4.6 & 22.44 \\
\hline 17 & Nessa Mud Snails & Nassarius sp. & $8.16 \%$ & - & 60.5 \\
\hline 18 & Land Hermit Crab & Coenobita sp. & $6.12 \%$ & - & 7.3 \\
\hline
\end{tabular}

Table 1 showed the results of the catch composition of the folded cube fishing pot consisted of 18 types of species. Among the catch, 12 of them were fish species, 3 swimmer crabs, $1 \mathrm{crab}, 1$ land hermit crab, and 1 type of snail species. The catching result of folded cube fish pots was classified into five types: Fish group which measured $48.97 \%$ of the total catch, crabs group (29.59\%), swimmer crabs (7.1\%), Land hermit crab $(6.12 \%)$, and mud snails (8.16\%). Pig Faced Leather Jacket (Paramonacanthus choirocephalus) also known locally as Bukur fish, was the highest number of trapped species in the fish group based on the total catch number with the catch percentage of $9.18 \%$. The most caught species was Twospined Arm Swimming Crab (Charybdis anisodon) amounting 29.59\% from the total catch, with the average of length is $4.6 \mathrm{~cm}$ and the average weight was $22.44 \mathrm{gr}$. The composition result of the folded cube fish pot is provided in figure 4.

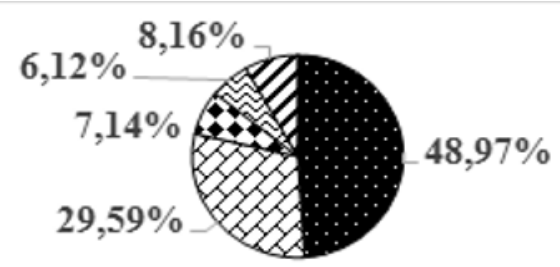

- Fish $\square$ Crabs $\square$ Swimmer Crab $\otimes$ Crustacea $\square$ Snail

Fig. 4. The composition result of folded cube fishing pot 
Figure 4 showed that the composition result of folded cube fishing pot in the sea of Tuban was classified based on the type of catch into 5 categories. The catch composition result was dominated by fish species. The result distribution of fish was $48.97 \%$ of the total catch. The result of crab was $29.59 \%$, snail $8.16 \%$, crucifix crab $7.14 \%$ and land hermit crab was the lowest with $6.12 \%$ of the total catch. The catch result of each trip has a different weight and rate. The catch rate for 10 trips using folded cube fish pot in the sea of Tuban is provided in figure 5.
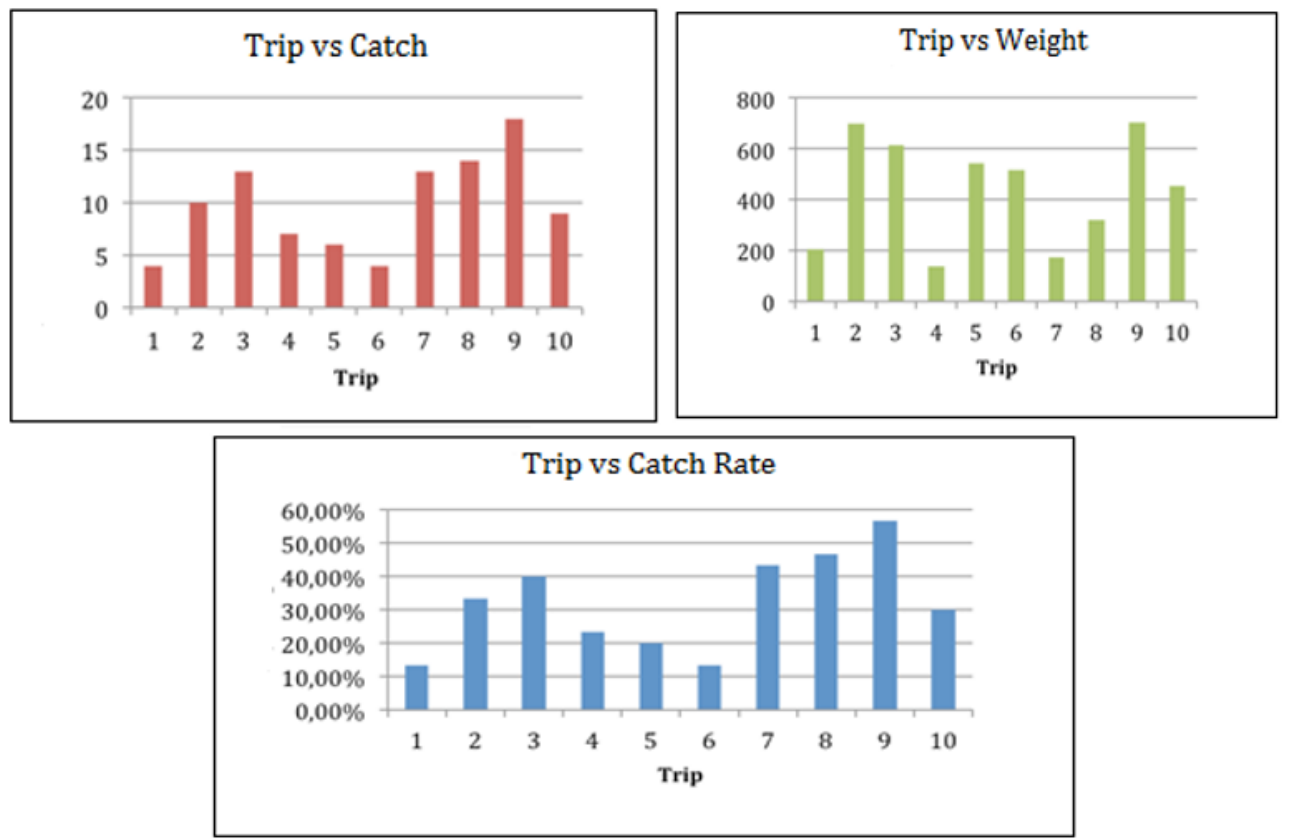

Fig. 5. Diagram of the total catch, total weight, and catch rate every trip

Figure 5 showed the average catching rate of folded cube fish pot in every trip was $32 \%$ with an average weight of $436.58 \mathrm{gr}$. The lowest catching rate of folded cube fish pot is $13.33 \%$ with $515 \mathrm{gr} /$ trip or $0.51 \mathrm{~kg} /$ trip catching weight result. The highest cathing rate of folded cube fish pot is $56.66 \%$ with $703 \mathrm{gr} /$ trip or $0.70 \mathrm{~kg} /$ trip catching weight result.

\subsection{Discussion}

Fish pots are considered eco-friendly fish catching tool because they do not catch all kinds of fish in a certain area. Instead, they catch a certain target of fish such as demersal fish, crabs and crucifix crab. Catching fish using fish pots is usually done in a muddy, sandy and rocky substrate [3]. The highest catching result of fish is obtained by using folded cube fish pots in the sea of Tuban which is characterized by a muddy, sandy and rocky substrate. Indrayanti et al [17] state that the area of fish catching is temporary. There will always be a change and shift following the movement of the environmental conditions because of the nature of fish which are always seeking for more suitable habitat. Furthermore, the habitat is significantly determined by the condition of oceanographic parameters such as sea surface temperature, salinity, chlorophyll-a, ocean current velocity, etc. All of these are determining the dynamics and movement of the seawater either vertically or horizontally, which in turn influenced the fish distribution in the sea. Muldiani [4] states that a suitable area for the usage of fish pots is the sea area with either muddy, sandy or rocky substrates, depending on the catch target. 
The result of catch composition is different from the results from previous research by Ferdiansyah (2017) [5] which was conducted on March-June by using various kinds of folded fish pots which focused on capturing flower crab (Portunus pelagicus) species. From the previous research mentioned before, the percentage of the catching effectiveness was $26,43 \%$ for folded square fish pots, $11,43 \%$ for modified folded square fish pots, $19,23 \%$ for folded dome fish pots, and $42,85 \%$ for modified folded dome fish pots. In the current research, the catching result composition of folded cube fish pots is more diverse than the catching result from the research previously mentioned [5]. Luhur (2012) [6] stated that the difference of catching result composition can be caused by the area, period, and also the catcher tool used. A significant difference in the catch result composition can also be caused by the different number of entrance in every fish pots used. The previous research conducted by [5], using fish pots that have horizontal entrance shape are commonly used to catch crucifix crab and crabs. Fish pots with horizontal-shaped entrace are designed to enable crucifix crab/crabs getting in and to block the unwanted targets other than crucifix crab/crabs to enter the fish pot. Therefore, the catching result composition is dominated by the species of crucifix crab (Portunus pelagicus). The benefit of using folded cube fish pots compared to the other types of fish catcher is the ability to obtain more diverse catch result composition.

In accordance with [7], fish pots with a dome design have 2.5 better catching ability than square fish pots. Catching crucifix crab by using fish pots have good selectivity and the ability to catch them in an intact and living condition, thus the quality is guaranteed. Another research by Supardjo et al (2018) [8], added an escape gap in dome-shaped fish pots. The escape gap was intentionally constructed, thus the undersized crucifix crab or other bycatch species can escape from the fish pots. Furthermore, another research conducted by Rachman et al (2017) [9] developed a new fish pot design which was a cube fish pot featured with either square or round funnel. The result showed that the catching result was dominated by a group of fish. The lack of the catcher was its big size and unfoldable, thus consumed a relatively wider space while carried on a boat. In this research, the catcher tool used was folded cube fish pot which is a modification from the research done by [9].

The lower catching rate was found in previous research by Hakim (2015) [10], who assessed the catching rate of dome fish pot in the sea of Tuban, found that the catching rate of fish pot was $863,75 \mathrm{gr} /$ trip or $0,86 \mathrm{~kg} /$ trip. The higher cathing rate was found in previous research by Alim (2016) [11] who studied the catching result of folded fish pot with soaked bait, found that the cathing rate of fish pot with smoked liquid bait was 344,5 gr/trip, shrimp paste was 158,6 gr/trip, and the control bait was 190,7 gr/trip. Similarly, the research conducted by Fachrudin et al (2013) [12] of fish pot catching rate in Demak Regency showed that the cathing rate of fish pot was $1,2 \mathrm{~kg} /$ trip. The catch result of fish pot compared to the former researches indicated that the catch between November to December 2018 in the sea of Tuban was lower than the catching result in the sea of Tuban, Bekasi, and Demak in 2015. The catching result and the catching rate are determined by several factors such as bait, migration and the choice of fishing ground. This notion is also supported by [13] who stated that the catching result fluctuation of various fish pot types is caused by 3 factors which are migration and daily shifts (seasonal or annual shift of the fish), the diversity of fish size in a population, and the placement of fish pot (it is because fish pot is passive and settled down in a certain place).

According to Caesario (2011) [14], bait can influence and determine the effectivity of fish pot in catching fish. By the presence of the bait's smell, the fish will be lured to get in the trap or fish pot. The crustacea's olfactory is very sensitive and accurate in locating the food or the source of the smell. Another determining factor that causes the catching rate of folded cube fish pot is lower than other folded fish pots is the location of fishing ground. This notion is supported by the research of Arios et al (2013) [15] which found that the impact of 
environmental and oceanographic conditions holds a significant role in the shift of CPUE/trap rate, while rain and wind have a direct impact on the activity and catching result. The fluctuation of production value related to the cathing result is influenced by the location of fishing ground. In determining the fishing ground, the fishermen did it in accordance with their experience in the sea.

The research was conducted between November to December 2018, thus the catch result in these months was not as high or as many as in the usual fish season. This happened because from November to December is considered west monsoon and transitional monsoon season which can cause the emergence of high sea current, thus the fishermen cannot reach the intended fishing ground. According to Nontji (1987) [16], the fish catching season is significantly influenced by the current pattern. In Indonesia, the surface current will change every half year, which resulted in the change of wind direction in every season. Another factor that influences the fish catching season is the wind because it can cause the emergence of current and wave on the surface of the sea, and also the rainfall which can lower the salinity of the seawater. Because of the presence of wind direction, there are phenomenons known as west and east monsoon season, and also transitional season between west-east/east-west monsoon. The transitional season is locally known as pancaroba.

\section{Conclusion}

The catching result of folded cube fish pots in the sea of Tuban consisted of 18 species of fish. The catch composition was dominated by the fish group. However, based on the species caught it was dominated by Two-spined arm swimming crab. The catch result was in accordance with the expected target, which is fish group. The average catch rate was still relatively low, one of the reasons is that the fishing installation was carried out during high waves. The research concluded that the use of folded cube fish pots is very suitable and capable in improving the fish catching result for the fishermen in the sea of Tuban, because it is more effective, efficient, sustainable, and also in accordance with the fish capture policy. Further research is needed particularly to investigate the performance of the trap when more fish entrance is added in the folded cube fish pot.

\section{References}

1. Agency for Regional Development of East Java. Jumlah rumah tangga perikanan tangkap menurut kabupaten/kota dan subsektor di provinsi Jawa Timur 2015 update 12 November 2018. Accessed 20 Mei 2019. Retrieved from https://jatim.bps.go.id/ (2018)

2. M. T. I. Perdana, H. Boesono, and Sardiyatmo. Influence of Bait and Soaking Time of Jebak ( Collapsible Trap) to Swimming Crab's ( Portunus pelagicus) Catch in the Semat Village, Jepara. Journal of Fisheries Resources Utilization Management and Technology. 5( 1). 1-8 (2016)

3. FAO. Code of Conduct for Responsible Fisheries FAO. Rome. 41p (1995)

4. D. Muldiani. Analisis Hasil Tangkapan Rajungan Pada Bubu Lipat Dengan Konstruksi Berbeda Di Perairan Kronjo, Kabupaten Tangerang. Thesis. Bogor Agricultural Institute. Bogor (2007)

5. M. R. Ferdiansyah, et al. The Comparison Between Trap Catcher Folding Box Traps With Folding Dome Traps To Catch Crabs (Portunus pelagicus) In Rembang Water Bond, Central Java. Indonesian Journal of Capture Fisheries 1 (01) (2015)

6. N. Luhur. Komposisi Hasil Tangkapan Bubu Lipat Di Pantai Drini Kabupaten Gunungkidul. Thesis. Universitas Gadjah Mada. Yogyakarta (2012) 
7. Zarochman. Konstruksi Dan Performa Bubu Kubah Pintu Samping Untuk Penangkapan Rajungan. Yogyakarta : Prosiding Semnaskan UGM (PI-02) :503-525 (2014)

8. Supardjo, Djumanto, S. N. Syahrifudin, I. Sambudi, N. Yasmin, N. Kurniawati, T. Y. Amanta, Z. Hasan, M. Trihadiyani, and O. Dwi. Celah Pelolosan Pada Bubu Kubah Terhadap Hasil Tangkapan Rajungan (Portunus pelagicus) Di Perairan Laut Jawa Utara Kabupaten Rembang. Faculty of Agriculture. Universitas Gadjah Mada. Yogyakarta (2018)

9. F. Rachman et al. Desain Dan Aplikasi Fish Trap Di Perairan Laut Kabupaten Tuban Jawa Timur. Laporan Akhir Peningkatan Kapasitas Peneliti Dosen Muda. Fakultas Pertanian Universitas Gadjah Mada. Yogyakarta (2017)

10. L. Hakim. Komposisi dan Laju Tangkap Ikan Hasil Bubu Kubah di Perairan Laut Kabupaten Tuban. Thesis. Faculty of Agriculture. Universitas Gadjah Mada (2015)

11. F. Alim. Hasil Tangkapan Bubu Lipat Menggunakan Umpan yang direndam dalam Larutan Terasi dan Asap Cair di Desa Paljaya Kabupaten Bekasi. Thesis. Faculty of Agriculture. Universitas Gadjah Mada (2016)

12. Fachrudin, B. C. Pratiwi, and Zahrudin. Laporan Uji Coba Alat Tangkap Bubu Rajungan di Kabupaten Demak. Balai Besar Pengembangan Penangkapan Ikan. Semarang (2013)

13. B. Soegiri, B. C. Pratiwi, Z. Wassahua. Laporan Uji Coba Alat Tangkap Bubu Rajungan di Kabupaten Jepara. BBPI. Semarang (2013)

14. R. Caesario. Perbedaan Bobot dan Posisi Umpan Terhadap Hasil Tangkapan Rajungan Pada Bubu Lipat di Desa Mayangan, Kabupaten Subang. Thesis. Faculty of Fisheries and Marine Science. Bogor Agricultural Institute (2011)

15. A. H. Arios, A. Solichin dan S.W. Saputra. Fishing Result Analysis of Rajungan (Portunus pelagicus) by Using Folded Bubu as A Fishing Gear That was Done in TPI Tanjung Sari, Rembang. Journal Of Management Aquatic Resources 2: 243 - 248 (2013)

16. A. Nontji. Laut Nusantara. Djembatan. Jakarta (1987)

17. Indrayani, et al. Penentuan Karakteristik Habitat Daerah Potensial Ikan Pelagis Kecil Dengan Pendekatan Spasial Di Perairan Sinjai. Faculty of Fisheries and Marine Science. Universitas Hasanuddin. Makasar (2012) 